\title{
Effect of operating pressure on direct biomethane production from carbon dioxide and exogenous hydrogen in the anaerobic digestion of sewage sludge
}

Israel Díaz $^{\text {a }}$ *, Fernando Fdz-Polanco $^{\text {a b }}$, Boldwin Mutsvene $^{c \text { d }}$, María Fdz-Polanco ${ }^{\text {b }}$

${ }^{a}$ Department of Chemical Engineering and Environmental Technology, University of Valladolid, Dr. Mergelina s/n, 47011 Valladolid, Spain.

${ }^{b}$ Institute of Sustainable Processes, University of Valladolid, Dr. Mergelina s/n, 47011 Valladolid, Spain.

${ }^{c}$ Department of Chemical Engineering, Durban University of Technology, 70 Steve Biko Rd, Musgrave, Berea, 4001, South Africa.

${ }^{\mathrm{d}}$ Institute for Water and Wastewater Technology, DUT, Musgrave, Berea, Durban, 4001, South Africa.

*Author for correspondence: israel.diaz@iq.uva.es

\begin{abstract}
The development of biological Power-to-Methane in-situ technologies aimed at producing biomethane directly in a single anaerobic digestion unit by the supply of external hydrogen, find its limiting step in the gas-to-liquid mass transfer of poorly soluble hydrogen. Increasing the operating pressure with an exogenous hydrogen supply could enhance transfer rates of hydrogen and carbon dioxide (enriching gas phase with methane) and simultaneously control the liquid media $\mathrm{pH}$ because the methanation of hydrogen and carbon dioxide prevents the acidification caused by carbon dioxide/bicarbonate equilibrium displacement. Thus, the feasibility of operating the anaerobic digestion of sludge at a pressure higher than the atmospheric pressure with an exogenous hydrogen supply to improve the solubilisation of hydrogen and subsequent bioconversion of hydrogen and carbon dioxide into methane by methanogenic archaea was studied. A mesophilic sludge digester (35 L) was operated at variable absolute pressure up to $300 \mathrm{kPa}$. Hydrogen was continuously supplied through the sludge recirculation stream, coupled to a static mixer. Hydrogen conversion increased with the operating pressure (up to $99 \%$ ), and the methane concentration in the digester off-gas averaged $92.9 \pm 2.3 \%$ at $300 \mathrm{kPa}$ (maximum of 95.2\%). $\mathrm{pH}$ approached 7 under such conditions, and the efficiency of organic matter removal was similar to that observed during conventional anaerobic digestion at atmospheric pressure without a detrimental accumulation of volatile fatty acids. This study confirmed that increasing the system pressure (mass transfer driving force) can be a viable alternative to high energy-consuming
\end{abstract}


mixing methods to enhance the hydrogen gas-liquid mass transfer.

Keywords: biomethane, in-situ biogas upgrading, methanation of $\mathrm{CO}_{2}$, power-to-methane, pressure, sludge digestion.

\section{Introduction}

\subsection{Anaerobic digestion, biogas production and utilisation}

Biomass is one of the largest sources of carbonaceous material available to produce renewable energy. Anaerobic digestion (AD) is a popular method for waste treatment that produces biogas and stabilises organic waste into a digested biomass that can find uses as fertiliser and for soil reclamation. Biogas is regarded as an alternative renewable energy source and can be considered to be carbon-neutral [13]. In 2016 the biogas production in the EU was equivalent to 16,000 ktoe which corresponds to approximately $8 \%$ of the total primary energy produced by renewable energy sources. This biogas is produced in plants of varying sizes ranging from $2 \mathrm{~kW}$ to $20 \mathrm{MW}$ [4].

Based on the chemical composition of the substrate and $\mathrm{pH}$ of the digester, biogas is a mixture of $\mathrm{CH}_{4}$ (50-70\%) and $\mathrm{CO}_{2}(30-50 \%)$, with low concentrations of $\mathrm{H}_{2} \mathrm{~S}, \mathrm{~N}_{2}, \mathrm{O}_{2}, \mathrm{NH}_{3}, \mathrm{CO}$, siloxanes and volatile organic compounds (VOCs) [5]. The high $\mathrm{CO}_{2}$ content limits the uses of biogas that in practice are restricted to the production of heat and electricity. Combined Heat and Power (CHP) engines are commonly used to produce electricity with efficiency above $40 \%$, depending on the type of gas engines and size. Biogas played a pivotal role in producing 61 TWh (219 PJ) of electrical energy within the European Union (EU), and in 2015 about 26.6 PJ heat energy was distributed to the district heating networks [4].

The new policies put in place to mitigate the environmental impact of the use of fossil fuels are hinged on the use of alternative renewable energy sources. The EU has ambitiously pronounced the goal of creating a competitive low carbon economy realising between $80 \%$ and $95 \%$ GHG emission reduction by 2050 . Moreover, the production of alternative renewable energy sources can be between $55 \%$ and $75 \%$ of gross final energy use [6].

To expand the potential uses of biogas, it is imperative to implement upgrading technologies to improve its characteristics and turn it into a product with more valuable uses. As a means to upgrade biogas to fuel of high calorific value, there are two major technologies, those that eliminate $\mathrm{CO}_{2}$ and those that transform (valorise) it, preferably into methane. The leading $\mathrm{CO}_{2}$ removal physical/chemical 
established technologies are water scrubbing, organic solvents or chemical solutions, pressure swing adsorption, membrane separation and cryogenic $\mathrm{CO}_{2}$ separation. These removal technologies dominate the biogas upgrading processes nowadays although they have both economic and environmental limitations; in particular, the evacuation to the atmosphere of between 1 and $2 \%$ of the methane fed in the process.

The biological $\mathrm{CO}_{2}$ valorisation process is based on $\mathrm{CO}_{2}$ transport from the bulk of the biogas to a microbial medium followed by different pathways of autotrophic uptake of $\mathrm{CO}_{2} \cdot \mathrm{CO}_{2}$ can be used as a substrate for the growth of photosynthetic microalgae, which can later be used as a feed for the generation of biofuels or valuable products [5,7]. Alternatively, a biological reduction of $\mathrm{CO}_{2}$ to $\mathrm{CH}_{4}$ can be performed through $\mathrm{H}_{2}$ injection into a bioreactor rich in archaea (hydrogenotrophic methanogenesis). To produce biomethane, a two-stage process is carried out: Firstly, $\mathrm{H}_{2}$ is generated by electrolysing water using surplus electricity and, secondly, the yielded $\mathrm{H}_{2}$ is injected to the anaerobic bioreactor to react with $\mathrm{CO}_{2}$ in the biogas to produce $\mathrm{CH}_{4}$.

The latter technology has been eased by the increasing implementation of renewable energy production technologies, particularly solar and wind power. One of the limitations of these technologies is the difficulty encountered in storing excess electrical energy during peak production periods. The storage of electrical energy can be achieved in the form of chemical energy. Thus, the aim of different Power to $\mathrm{Gas}(\mathrm{PtG})$ processes is to link the power grid to the gas grid by the conversion of excess power into gas which meets the legislative gazetted gas quality to be injected into the grid. Reviews highlighting the essence of PtG technologies for dealing with renewable energies can be found elsewhere [8,9]. One of the main ways of converting electricity into gas is based on the conversion of biogas into biomethane.

\subsection{Biological $\mathrm{CO}_{2}$ methanation}

Biological Power to Methane (PtM) processes are based on the reaction (Eq.1):

$\mathrm{CO}_{2(\mathrm{~g})}+4 \mathrm{H}_{2}(\mathrm{~g}) \rightarrow \mathrm{CH}_{4}(\mathrm{~g})+2 \mathrm{H}_{2} \mathrm{O}_{(\mathrm{g})} \quad \Delta G=-165 \mathrm{~kJ} \mathrm{~mol}^{-1}$

When hydrogenotrophic methanogenic archaea perform this exergonic reaction, it is known as the biological $\mathrm{CO}_{2}$-methanation process [10]. From an energetic point of view, the stoichiometry of the reaction is adverse because 2 moles of $\mathrm{H}_{2}$ are lost to form 2 moles of $\mathrm{H}_{2} \mathrm{O}$; in fact, from 4 moles of $\mathrm{H}_{2}$ only form 1 mole of $\mathrm{CH}_{4}$. Taking into account the combustion heats of $\mathrm{H}_{2}\left(\Delta \mathrm{H}^{0} \mathrm{C}=-286 \mathrm{~kJ} \mathrm{~mol}^{-1}\right)$ and 
$\mathrm{CH}_{4}\left(\Delta \mathrm{H}^{0} \mathrm{C}=-889 \mathrm{~kJ} \mathrm{~mol}^{-1}\right)$, the formation of 1 mole of $\mathrm{CH}_{4}$ from 4 moles of $\mathrm{H}_{2}$ represents a loss of $22 \%$ of the $\mathrm{H}_{2}$ energy potential.

Biogas from $\mathrm{AD}$ is the natural source of $\mathrm{CO}_{2}$ for biological conversion to $\mathrm{CH}_{4}$; thus, biogas can be upgraded to biomethane whose characteristics and composition can meet the legislative quality required to be injected in the grid and considered as a substitute of natural gas [9]. Most applications are conducted in "ex-situ" using an external biological reactor that is fed with a mixture of $\mathrm{H}_{2}$ and biogas that exits the digester [11-13]. At the lab-scale $\mathrm{CH}_{4}$ formation rates (MFR) up to $40 \mathrm{~L} \mathrm{~L}_{\mathrm{R}}^{-1} \mathrm{~d}^{-1}$ have been reported in plug-flow bioreactors [14]; at this rate, effective integration of ex-situ upgrading was estimated in WWTP [15]. Nonetheless, at pilot and demo scales, long-term and stable production was achieved only in biotrickling filters at MFR of 3.1 $\mathrm{L} \mathrm{LR}^{-1} \mathrm{~d}^{-1}[11]$.

\subsection{In-situ biomethane production by $\mathrm{H}_{2}$ supply to the anaerobic digester}

In recent years, "in-situ" systems in which $\mathrm{H}_{2}$ is directly injected into the anaerobic digester so that archaea directly utilise $\mathrm{H}_{2}$ to deplete $\mathrm{CO}_{2}$ from the biogas have been applied at laboratory or pilot scale. With an efficient conversion, biomethane could be directly produced from the digester or after refining in an ex-situ stage [16]. The gas-to-liquid mass transfer has been reported to be the limiting step of the process in increasing the purity of biomethane to $55-96 \%$ [17].

The first experimental work in which $\mathrm{H}_{2}$ is directly charged into the bioreactor was carried out in 2012 at laboratory scale, in batch operation mode, and thermophilic $\left(55^{\circ} \mathrm{C}\right)$ range [18]. The initial results were modest, the $\mathrm{CH}_{4}$ production rate was $22 \%$ higher in comparison to the control digester, and $\mathrm{CO}_{2}$ composition in the biogas was reduced to $15 \%$, while the control system reported $38 \%$. Also in 2012, it was demonstrated that the additional supply of $\mathrm{H}_{2}$ had an encouraging effect on the methanogenesis, but had no properly defined effect on the acetogenic process. The $\mathrm{H}_{2}$ injection mechanism (diffusers with different pore sizes) and the degree of liquid mixing were shown to have an impact on the gasliquid mass transfer of $\mathrm{H}_{2}$ and the biogas content. The $\mathrm{CH}_{4}$ concentration increased from 55 to $75 \%$ [19].

A continuous setup composed of two-stage reactors was presented in [20]. Biogas was upgraded to an average methane composition of $89 \%$ in the mesophilic digester and $85 \%$ in the thermophilic. The upsurge of hydrogenotrophic methanogenic microbes and syntrophic Desulfovibrio and the reduction of acetoclastic methanogens showed an $\mathrm{H}_{2}$-mediated shift towards the hydrogenotrophic pathway improving biogas upgrading. A similar behaviour revealing the shift toward the hydrogenotrophic 
pathway and the significant effect on reactor performance of the $\mathrm{H}_{2}: \mathrm{CO}_{2}$ ratio to avoid process instability were the main conclusions presented in [21]. Keeping the topic of $\mathrm{H}_{2} / \mathrm{CO}_{2}$ ratio, the systematic isotope analysis presented in [22] showed that surplus $\mathrm{H}_{2}$ injection caused an increase in dissolved $\mathrm{H}_{2}$ to a thermodynamic limit that inhibits the decomposition of VFA and stimulates homoacetogens for the generation of acetate from $\mathrm{CO}_{2}$ and $\mathrm{H}_{2}$.

Maintaining continuous operation, the setup operated in [20] comprised of a granular digestor coupled to a separate chamber in which $\mathrm{H}_{2}$ was added. To bolster gas-liquid mass transfer, the recirculated liquid and gas, and chamber orientation were optimised, $\mathrm{CO}_{2}$ composition in the biogas dwindled from 42 to $10 \%$, and the end product was upgraded from 58 to $82 \%$ methane composition.

Conversely, $\mathrm{pH}$ increase was noted in several studies $(8$ - 9) due to the consumption of bicarbonate [16,18,23-25], and eventually, VFA accumulation and inhibition of methanogenesis. The acid-base equilibrium between dissolved $\mathrm{CO}_{2}$ and $\mathrm{HCO}_{3}{ }^{-}$at $\mathrm{pH}$ around 7 , in which $\mathrm{AD}$ naturally occurs (Figure 1.a), is altered by exogenous $\mathrm{H}_{2}$ supply. $\mathrm{CO}_{2}$ consumption in Eq. 1 causes a decrease in dissolved $\mathrm{CO}_{2}$ concentration and the subsequent displacement of acid-base equilibrium with $\mathrm{HCO}_{3}^{-}$(Eq.2), consuming protons, and increasing $\mathrm{pH}$ (Figure 1.b).

$$
\mathrm{CO}_{2(\mathrm{aq})}+\mathrm{H}_{2} \mathrm{O} \leftarrow \rightarrow \mathrm{HCO}_{3}^{-}{ }_{(\mathrm{aq})}+\mathrm{H}^{+}{ }_{(\mathrm{aq})}
$$

The only real-scale study was carried out in a $1.110 \mathrm{~m}^{3}$ thermophilic digester treating manure, and a conventional Venturi device was used to inject by pulses the exogenous $\mathrm{H}_{2}$ [26]. The performance was very modest, reaching an $\mathrm{H}_{2}$ consumption rate of $15 \mathrm{LH}_{2} \mathrm{~m}^{-3} \mathrm{~h}^{-1}$ and consuming only $26 \%$ of the injected $\mathrm{H}_{2}$. In this sense and also for an in-situ system with pulse $\mathrm{H}_{2}$ addition, [27] underlines the relevance of methanogen adaption. 
Biogas



CONVENTIONAL AD $\left(\mathbf{P}_{\text {atm }}\right)$

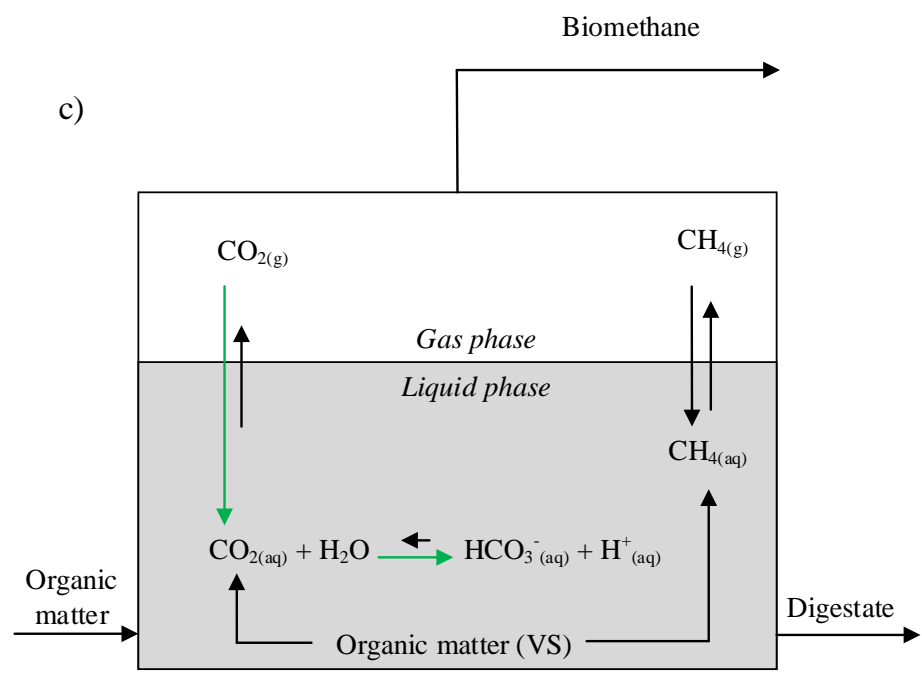

High-pressure AD $\left(\mathbf{P}>\mathbf{P}_{\text {atm }}\right)$

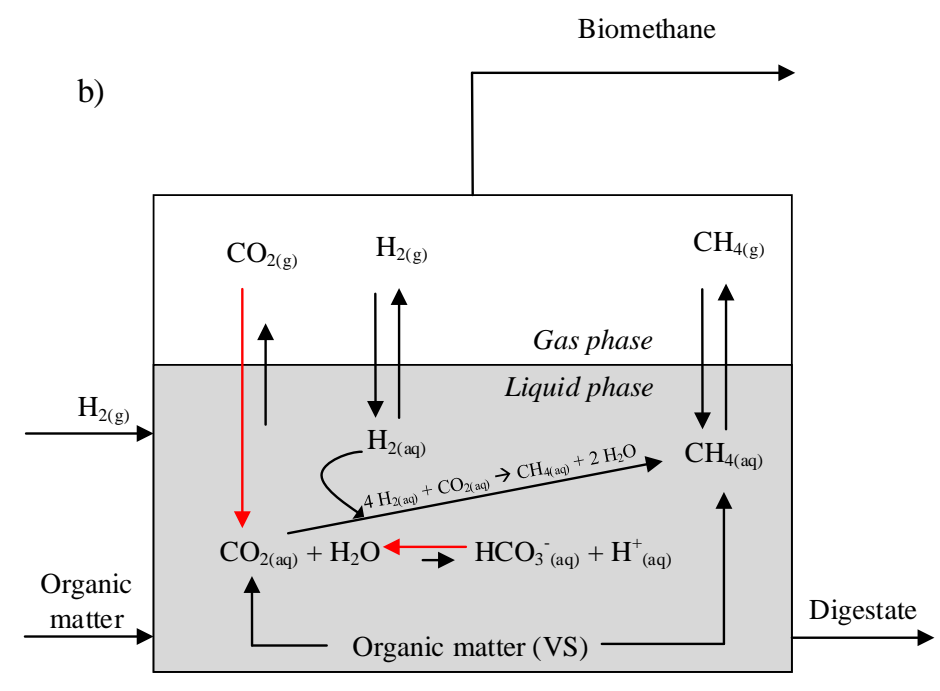

$\mathrm{AD}+\mathbf{H}_{2}\left(\mathbf{P}_{\text {atm }}\right)$

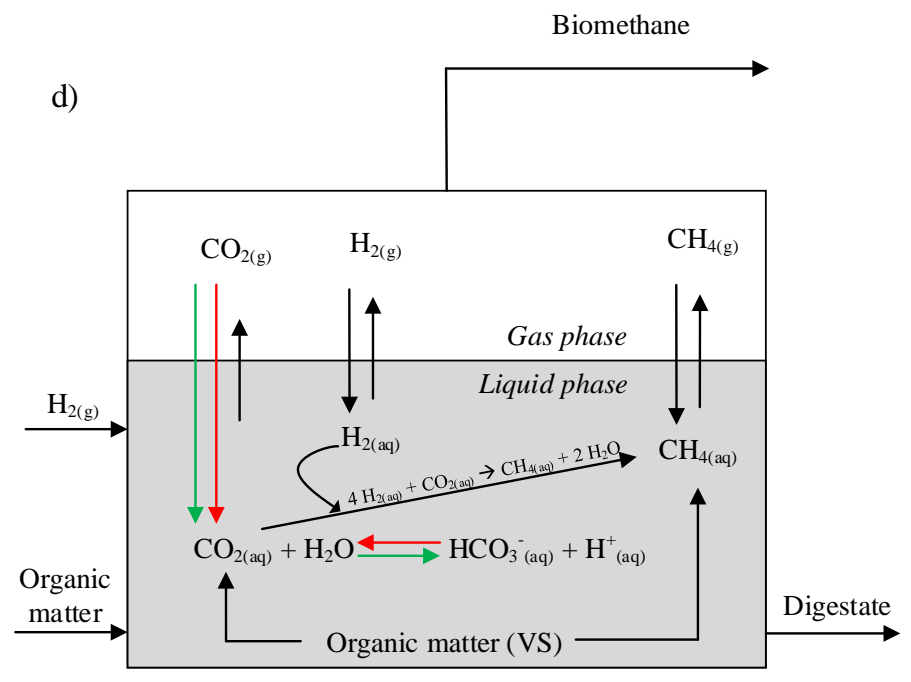

High pressure AD $+\mathbf{H}_{2}\left(\mathrm{P}>\mathbf{P}_{\mathrm{atm}}\right)$

Effect of methanation on $\mathrm{CO}_{2}$ equilibria

Effect of pressure on $\mathrm{CO}_{2}$ equilibria

Figure 1. Effect of pressure and exogenous $\mathrm{H}_{2}$ supply on gas-liquid and acid-base equilibria of $\mathrm{CO}_{2}$.

a) Conventional $\mathrm{AD}$ at atmospheric pressure. b) Equilibria displacement by methanation of $\mathrm{H}_{2}$ and $\mathrm{CO}_{2}$ at atmospheric pressure. c) Equilibria displacement by increasing operating pressure. d) The combined effect on $\mathrm{CO}_{2}$ equilibria of methanation and increased operating pressure. 


\subsubsection{Driving-force oriented mass transfer of $\mathrm{H}_{2}$ by increasing the operating pressure}

The low solubility of $\mathrm{H}_{2}$ in water and poor mass transfer from the gas to the liquid phase is the limitingstep for the conversion. The rate of $\mathrm{H}_{2}$ transferred to the liquid phase can be described as:

$\mathrm{r}_{\mathrm{H} 2}=\mathrm{V} \mathrm{k}_{\mathrm{L}} \mathrm{a}\left(\mathrm{P}_{\mathrm{H} 2, \mathrm{G}} / \mathrm{H}-\mathrm{c}_{\mathrm{H} 2, \mathrm{~L}}\right)$

Where $\mathrm{r}_{\mathrm{H} 2}$ is the molar rate of $\mathrm{H}_{2}$ transferred to the liquid phase $\left(\mathrm{mol} \mathrm{h}^{-1}\right), \mathrm{V}$ is the volume of the reactor (L), $\mathrm{k}_{\mathrm{L}}$ is the specific mass transfer coefficient for $\mathrm{H}_{2}\left(\mathrm{~h}^{-1}\right), \mathrm{P}_{\mathrm{H} 2, \mathrm{G}} / \mathrm{H}$ is the concentration of $\mathrm{H}_{2}$ (mol

$\left.\mathrm{L}^{-1}\right)$ in the gas-liquid interphase in equilibrium with the gas phase according to Henry`s Law $\left(\mathrm{H}_{\mathrm{H} 2}\right.$ $\left.\left(35^{\circ} \mathrm{C}\right)=7.5 \cdot 10^{-5} \mathrm{~mol} \mathrm{~L}^{-1} \mathrm{~atm}^{-1}\right)$ and $\mathrm{C}_{\mathrm{H} 2, \mathrm{~L}}$ is the concentration of dissolved $\mathrm{H}_{2}$ in the global liquid phase $\left(\mathrm{mol} \mathrm{L}^{-1}\right)$. For a given volume of reaction, the rate of $\mathrm{H}_{2}$ can be increased, whether by increasing the mass transfer coefficient or by increasing the partial pressure of $\mathrm{H}_{2}$ in the bioreactor.

As mentioned in section 1.3, several studies have shown different approaches to facilitate biomethanation of $\mathrm{H}_{2}$ and $\mathrm{CO}_{2}$ by increasing the specific mass transfer coefficient; nonetheless, there is a knowledge gap regarding the effect of the concentration gradient. On this subject, a higher operating pressure increases the concentration gradient (driving force for gas-to-liquid mass transfer) and, thus, the solubility of gases in water. The solubility of $\mathrm{CO}_{2}\left(\mathrm{H}_{\mathrm{CO} 2}\left(35^{\circ} \mathrm{C}\right)=2.7 \cdot 10^{-2} \mathrm{~mol} \mathrm{~L}^{-1} \mathrm{~atm}^{-}\right.$ $\left.{ }^{1}\right)$ is notably more significant than that of $\mathrm{CH}_{4}\left(\mathrm{H}_{\mathrm{CH} 4}\left(35^{\circ} \mathrm{C}\right)=1.2 \cdot 10^{-3} \mathrm{~mol} \mathrm{~L}^{-1} \mathrm{~atm}^{-1}\right)$; then, an increase in the operating pressure can directly enrich biogas in $\mathrm{CH}_{4}$ (Figure 1.c). This was confirmed in [28]; where high-pressure (up to $1100 \mathrm{kPa}$ ) $\mathrm{AD}$ of acetate was accompanied by an enhancement in the concentration of $\mathrm{CH}_{4}(74-86 \%)$ in the off-gas, owing to the greater solubility of $\mathrm{CO}_{2}$, at the expense of a lower $\mathrm{pH} \cdot(3-5)$. Further, an increase in the operating pressure also can improve $\mathrm{H}_{2}$ mass transfer to the liquid phase by increasing $\mathrm{P}_{\mathrm{H} 2}$ (Eq.3). This has been confirmed in the biological methanation carried out in pressurised single-culture CSTRs [30] and biotrickling filters [11,31], performed in a separate unit (ex-situ upgrading).

\subsection{Objectives, experimental hypothesis and novelty}

This study aims to evaluate the feasibility of producing biomethane from a digester of sewage sludge supplied with $\mathrm{H}_{2}$ at operating pressures higher than the atmospheric pressure. In this regard, an increase in the operating pressure of $\mathrm{AD}$ with exogenous $\mathrm{H}_{2}$ supply can synchronously increase the driving force for $\mathrm{H}_{2}$ mass transfer (Eq.3) and, hypothetically, counteract the expected decrease in $\mathrm{pH}$ because of $\mathrm{CO}_{2} / \mathrm{HCO}_{3}{ }^{-}$equilibrium displacement (Eq.2) with a larger $\mathrm{H}_{2}$ rate transferred to convert $\mathrm{CO}_{2}$ into $\mathrm{CH}_{4}$ according to Eq. 1 (Figure 1.d). 
Reported studies on exogenous $\mathrm{H}_{2}$ injection to anaerobic digesters have focused on increasing the specific mass transfer coefficient to ease the solubilisation of $\mathrm{H}_{2}$ at atmospheric pressure while the effect of increasing the concentration gradient of $\mathrm{H}_{2}$ at high pressure remains unexplored in anaerobic digesters; no in-situ studies have been reported about combined $\mathrm{H}_{2}$ supply and pressure increase. If feasible, a new pathway to apply the Power-to-Methane concept could be developed and optimised, in which mass transfer of $\mathrm{H}_{2}$ does not rely on high energy-demanding methods to increase the specific mass transfer coefficient, hence reducing the parasitic energy consumption in $\mathrm{CO}_{2}$-methanation and improving energy conservation.

\section{Materials and Methods}

\subsection{Experimental setup}

The digester had a cylindrical configuration (OD: $315 \mathrm{~mm}$ and $\mathrm{H}: 800 \mathrm{~mm}$ ), built of high-density polyethene (PE100 PN10, AENOR-N 001/34 UNE EN 12201) with a working volume of 35 L (total volume of $48 \mathrm{~L}$ ). The digester was insulated with polystyrene while the temperature was regulated and maintained using electric resistance coiled between the walls of the digester and the insulation material. Mixing was achieved by recirculating the sludge from the midpoint height to the bottom of the digester. $\mathrm{H}_{2}$ flowrate was controlled with a mass flow controller (GFC Aalborg, USA) and injected through the sludge recirculation stream. A static mixer (1/2-40C-4-12-2 Koflo, USA) was installed after the $\mathrm{H}_{2}$ dosing point to avoid the formation of large $\mathrm{H}_{2}$ bubbles (Figure 1). The operating pressure was controlled with an electrovalve (N263DVC M\&M international, Italy) embedded in the headspace of the digester and a gauge pressure probe (Cerabar PMC21 Endress Hausser. Switzerland). A vessel (3L) was used for gas expansion at the outlet of the digester. 


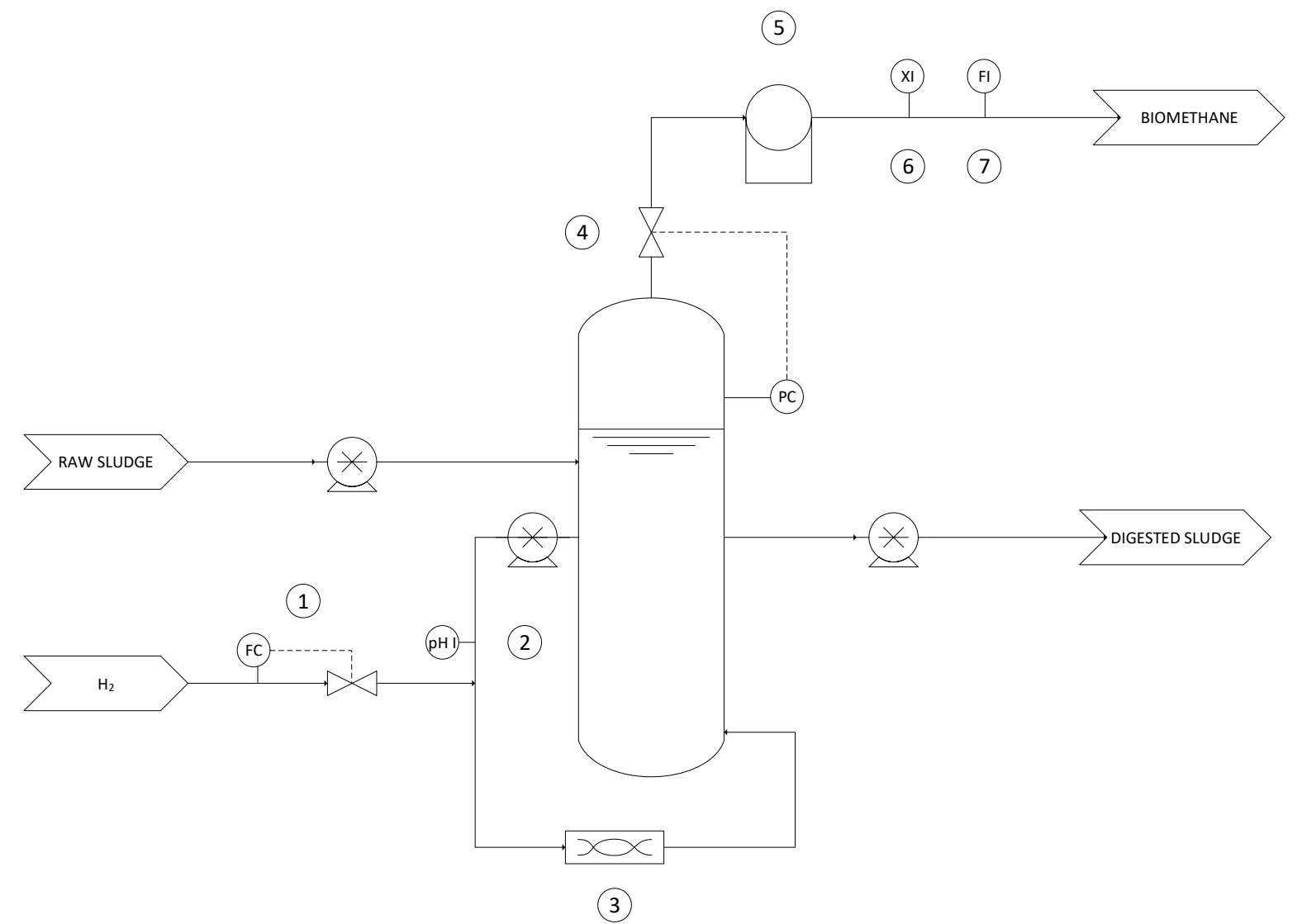

Figure 2. Process flow diagram of the experimental setup. 1. $\mathrm{H}_{2}$ Mass flow controller, 2. pH probe, 3. Static mixer, 4. P control valve, 5. Gas expansion vessel, 6. Gas sample point, 7. Gas flowmeter

\subsection{Operating conditions}

The digester was inoculated with anaerobic sludge from the WWTP of Valladolid (Spain). Inoculum presented a $\mathrm{pH}$ of 7.1 and the following concentrations: $\mathrm{VS}=1.0 \% \mathrm{w}$. , Total alkalinity $=4400 \mathrm{mg}$ $\mathrm{CaCO}_{3} \mathrm{~L}^{-1}$, TKN (Total Kjeldahl Nitrogen) $=1648 \mathrm{mg} \mathrm{L}^{-1}, \mathrm{~N}^{-N_{4}}{ }^{+}=725 \mathrm{mg} \mathrm{L}^{-1}$. The digester was operated under mesophilic conditions $\left(35 \pm 1{ }^{\circ} \mathrm{C}\right)$ and fed semi-continuously with mixed sludge, periodically collected from the same WWTP. Mixed sludge, from the primary clarifier and activated sludge, showed a variable concentration of organic matter according to seasonal changes, VS concentration was $1.3-2.8 \%$ (w.) and total COD between 19.9 and $45.4 \mathrm{~g} \mathrm{~L}^{-1}$ during the study. Feeding and discharge pumps were activated four times per day to achieve an HRT of $20 \mathrm{~d}$. Mixing was provided by sludge recirculation at a rate of $20 \mathrm{~L} \mathrm{Lr}_{r}^{-1} \mathrm{~d}^{-1}$.

The experiment consisted of 4 stages (I, II, III, IV) governed by the increasing operating pressures and $\mathrm{H}_{2}$ rates (Table 1). The pressure was increased until an average $\mathrm{CH} 4$ concentration in the off-gas was larger than 90\%. HRT was fixed, and OLR varied (between 0.80 and $1.31 \mathrm{gVS} \mathrm{Lr}^{-1} \mathrm{~d}^{-1}$ ) based on the concentration of collected raw sludge. After a setup period of $12 \mathrm{~d}$ at $\sim 150 \mathrm{kPa}$, the pressure was 
increased to $200 \mathrm{kPa}$ in stage I, $250 \mathrm{kPa}$ in stage II, and $300 \mathrm{kPa}$ in stage III at a fixed $\mathrm{H}_{2}$ rate of 0.45

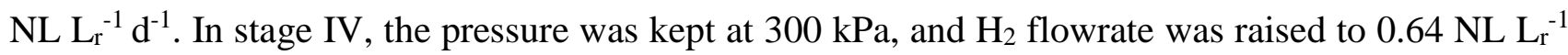
$\mathrm{d}^{-1} \cdot \mathrm{H}_{2}$ flowrate was below the stoichiometric requirement for the full conversion of expected $\mathrm{CO}_{2}$ during the whole experiment.

\subsection{Monitoring}

The experiment was monitored as follows: gas leaving the digester passed through an expansion vessel to measure daily flowrate by the liquid displacement method at atmospheric pressure. Gas composition $\left(\mathrm{CH}_{4}, \mathrm{CO}_{2}\right.$, and $\left.\mathrm{H}_{2}\right)$ was measured daily by GC-TCD (3800 VARIAN, USA), as reported elsewhere [32]. VFA concentration in digested sludge was determined weekly by GC-FID [33]. $\mathrm{pH}$ was monitored online with a probe (5364 Crison, Spain), and VS content, TKN, and $\mathrm{N}_{-} \mathrm{NH}_{4}{ }^{+}$in raw and digested sludge were weekly measured by using Standard Methods [34]. The total alkalinity of the inoculum and the total COD of raw sludge were also determined by Standard Methods [34].

Table 1. Overview of operating conditions and biomethane production during the experiment.

\begin{tabular}{lllll} 
Stage & I & II & III & IV \\
\hline Time & 12 & 61 & 117 & 158
\end{tabular}

(d)

\begin{tabular}{|c|c|c|c|c|}
\hline $\begin{array}{l}\text { Absolute pressure } \\
\text { (kPa) }\end{array}$ & $200 \pm 10$ & $250 \pm 10$ & $300 \pm 10$ & $300 \pm 10$ \\
\hline $\begin{array}{l}\mathrm{H}_{2} \text { flowrate } \\
\left(\mathrm{NL} \mathrm{Lr}^{-1} \mathrm{~d}^{-1}\right)\end{array}$ & 0.45 & 0.45 & 0.45 & 0.64 \\
\hline $\begin{array}{l}\text { Average OLR } \\
\left(g S_{\mathbf{r}^{-1}} \mathrm{~d}^{-1}\right)\end{array}$ & $0.92 \pm 0.23$ & $0.80 \pm 0.15$ & $1.31 \pm 0.08$ & $1.20 \pm 0.18$ \\
\hline $\begin{array}{l}\text { Average gas } \\
\text { productivity } \\
\left(\mathrm{NL} \mathbf{L r}^{-1} \mathbf{d}^{-1}\right)\end{array}$ & $0.44 \pm 0.10$ & $0.36 \pm 0.06$ & $0.51 \pm 0.12$ & $0.54 \pm 0.06$ \\
\hline \multicolumn{5}{|l|}{$\begin{array}{l}\text { Average gas } \\
\text { composition } \\
(\% \text { v.) }\end{array}$} \\
\hline $\mathrm{CH}_{4}$ & $69.4 \pm 5.8$ & $79.7 \pm 3.7$ & $85.7 \pm 4.1$ & $92.9 \pm 2.3$ \\
\hline $\mathrm{CO}_{2}$ & $15.2 \pm 4.0$ & $12.8 \pm 1.6$ & $12.6 \pm 3.0$ & $6.3 \pm 2.4$ \\
\hline $\mathbf{H}_{2}$ & $15.4 \pm 5.1$ & $7.5 \pm 3.1$ & $1.8 \pm 2.5$ & $0.8 \pm 0.3$ \\
\hline
\end{tabular}




\subsection{Calculations}

The calculations performed to estimate the mass flowrate of $\mathrm{CH}_{4}$ in the effluent stream assumed an ideal equilibrium according to Henry's law and a dimensionless Henry's constant of $1.2 \cdot 10^{-3} \mathrm{~mol} \mathrm{~L}$ ${ }^{1} \mathrm{~atm}^{-1}$ at $35^{\circ} \mathrm{C}[35]$.

The specific mass transfer coefficient of $\mathrm{H}_{2}$ was calculated according to Eq.3, where $\mathrm{P}_{\mathrm{H} 2, \mathrm{G}}$ was assumed to be the operating pressure in every stage of the study; since pure $\mathrm{H}_{2}$ was supplied through the sludge recirculation stream, bubbles of pure $\mathrm{H}_{2}$ were assumed to bubble up in the digester while mass transfer occurred. The amount of $\mathrm{H}_{2}$ transferred from the gas headspace to the liquid phase was neglected because of the low $\mathrm{H}_{2}$ concentration and the lack of gas recirculation for mixing. Dissolved $\mathrm{H}_{2}$ concentration $\left(\mathrm{C}_{\mathrm{H} 2, \mathrm{~L}}\right)$ was also neglected assuming that kinetics of Eq.1 did not limit the $\mathrm{CO}_{2-}$ methanation process. Molar rate of $\mathrm{H}_{2}$ transferred to the liquid phase $\left(\mathrm{r}_{\mathrm{H} 2}, \mathrm{~mol} \mathrm{~h}^{-1}\right)$ was calculated as the difference between $\mathrm{H}_{2}$ molar supply rate $\left(n_{H \dot{2}, I N}\right.$, mol h$\left.{ }^{-1}\right)$ and the molar rate of $\mathrm{H}_{2}$ leaving the digester $\left(n_{H 2, \text { OUT }}, \mathrm{mol} \mathrm{h}^{-1}\right)(\mathrm{Eq} .4)$ :

$\mathrm{r}_{\mathrm{H} 2}=n_{H \dot{2}, \mathrm{IN}}-n_{H 2, \mathrm{OUT}}$

The efficiency of $\mathrm{H}_{2}$ conversion $\left(\eta_{\mathrm{H} 2}, \%\right)$ was calculated through Eq.5:

$\eta_{H 2}=\frac{n_{H \dot{2}, I N}-n_{H 2, O U T}}{n_{H 2, I N}} \cdot 100$

Data from [23] was pegged as the reference for conventional AD to establish comparisons; a lab-scale digester $(20 \mathrm{~L})$ inoculated and fed with sludge from the same WWTP, operated at mesophilic conditions, at the same HRT to this study $(20 \mathrm{~d})$ and an average OLR of $1.3 \pm 0.2 \mathrm{gVS} \mathrm{L}_{\mathrm{r}}^{-1} \mathrm{~d}^{-1} \mathrm{during}$ the $119 \mathrm{~d}$ period. A biogas productivity of $0.65 \pm 0.16 \mathrm{NL} \mathrm{L}_{\mathrm{r}}^{-1} \mathrm{~d}^{-1}$ or $0.50 \pm 0.12 \mathrm{~L} \mathrm{gVS}_{\mathrm{fed}^{-1}}(65.7 \%$ $\mathrm{CH}_{4}$ and $34.3 \% \mathrm{CO}_{2}$ ) and a VS removal efficiency of $48.2 \pm 7.5 \%$ were recorded. $\mathrm{H}_{2}$ concentration in the biogas was below the detection limit during the whole period. To elucidate whether VS removal efficiency was different in this experiment with respect to the reference $\mathrm{AD}$, an unequal variances $t$ test (one tail) was applied in Microsoft Excel to compare the averages of both samples at a confidence level of $95 \%(\alpha=0.05)$. Atmospheric pressure considered for calculations (1 atm).

\section{Results and discussion}




\subsection{Consumption of $\mathrm{CO}_{2}$ to biomethane-rich gas}

During the experiment, the concentration of $\mathrm{CH}_{4}$ in the off-gas increased with operating pressure at a constant $\mathrm{H}_{2}$ supply rate (stages I, II and III) as shown in Figure 3; from an average $69.4 \%$ at $200 \mathrm{kPa}$ (stage I) to $79.7 \%$ at $250 \mathrm{kPa}$ (stage II) and $85.7 \%$ at $300 \mathrm{kPa}$. Contrarily, $\mathrm{CO}_{2}$ and $\mathrm{H}_{2}$ concentrations dropped accordingly (Table 1). The drop was relatively larger in the $\mathrm{H}_{2}$ concentration than that observed in $\mathrm{CO}_{2}$; this is a consequence of the stoichiometry of the $\mathrm{CO}_{2}$-methanation reaction (Eq.1) which requires $4 \mathrm{~mol}$ of $\mathrm{H}_{2}$ to convert $1 \mathrm{~mol}$ of $\mathrm{CO}_{2}$. Given the fact that a constant $\mathrm{H}_{2}$ flowrate was supplied during stages I to III, the increase in the operating pressure resulted in a higher $\mathrm{CH}_{4}$ concentration and lower $\mathrm{CO}_{2}$ and $\mathrm{H}_{2}$ concentrations.

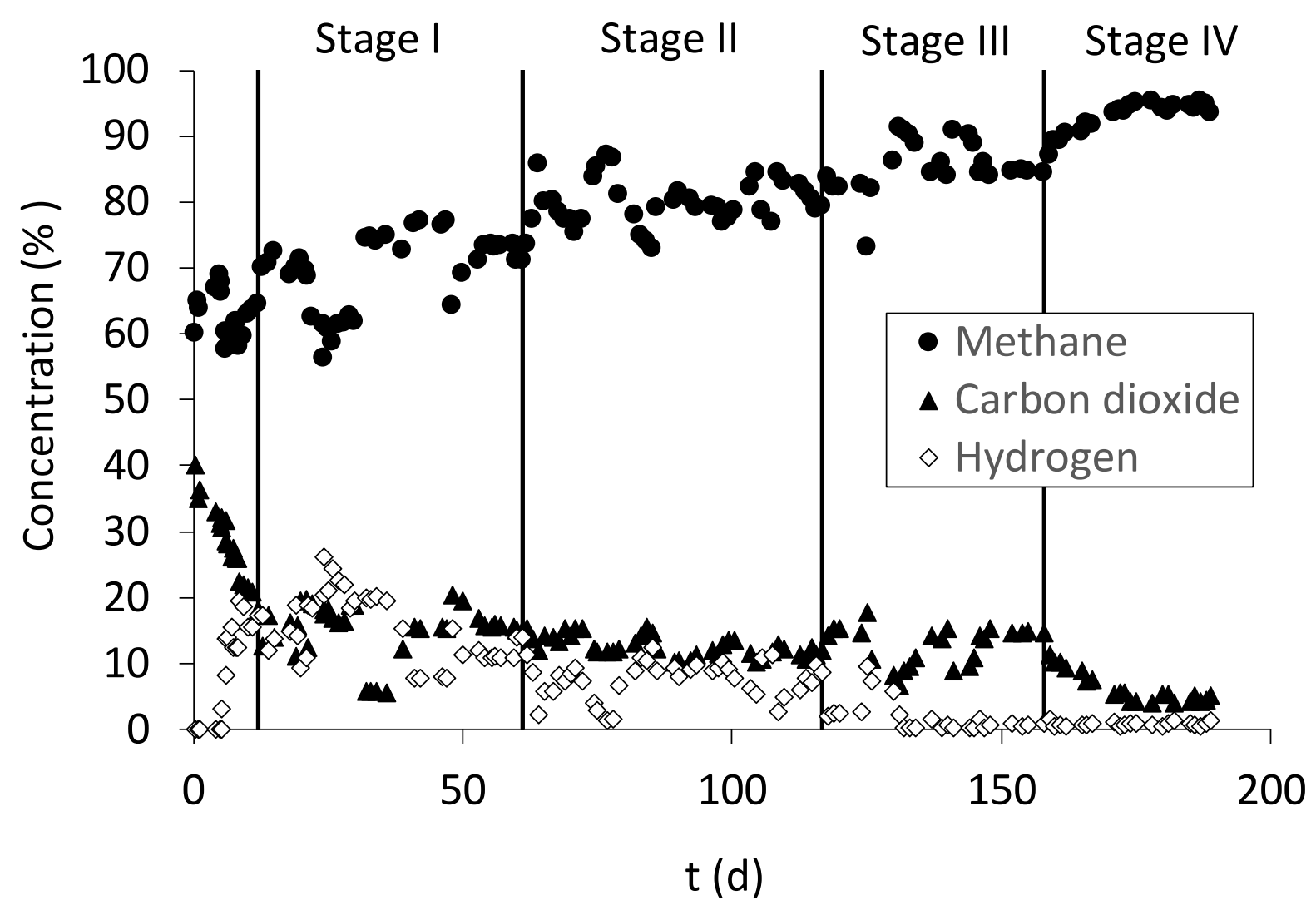

Figure 3. Evolution of the gas composition.

A lack of $\mathrm{H}_{2}$ for further $\mathrm{CO}_{2}$ conversion was detected at stage III; $\mathrm{H}_{2}$ concentration averaged $1.8 \%$ while $\mathrm{CO}_{2}$ concentration was $12.6 \%$ (Table 1). $\mathrm{H}_{2}$ was clearly the limiting reactant for higher $\mathrm{CO}_{2}$ removal; then, $\mathrm{H}_{2}$ supply rate was increased in stage IV to $0.64 \mathrm{NL} \mathrm{L}_{\mathrm{r}}^{-1} \mathrm{~d}^{-1}$. Consequently, $\mathrm{CH}_{4}$ concentration reached an average concentration of $92.9 \%$ during stage IV and a maximum of $95.2 \%$.

Then, biomethane with a $\mathrm{CH}_{4}$ concentration up to $95 \%$ in a digester of sludge operating at an absolute pressure of $300 \mathrm{kPa}$ was obtained. Increasing the operating pressure could be advantageously used to 
improve the overall $\mathrm{H}_{2}$ transference to the liquid phase. Due to this, an upsurge in the operating pressure brought about a positive effect on the efficiency of $\mathrm{H}_{2}$ conversion $\left(\eta_{\mathrm{H} 2}\right)$. During stage I, $\eta_{\mathrm{H} 2}$ was, on average, $78.8 \pm 8.4 \%$ and increased to $91.0 \pm 4.5 \%, 97.1 \pm 4.3 \%$ with operating pressure in stages II and III, respectively. When $\mathrm{H}_{2}$ flowrate was increased in stage IV, the $\eta_{\mathrm{H} 2}$ observed was 99.0 $\pm 0.4 \%$.

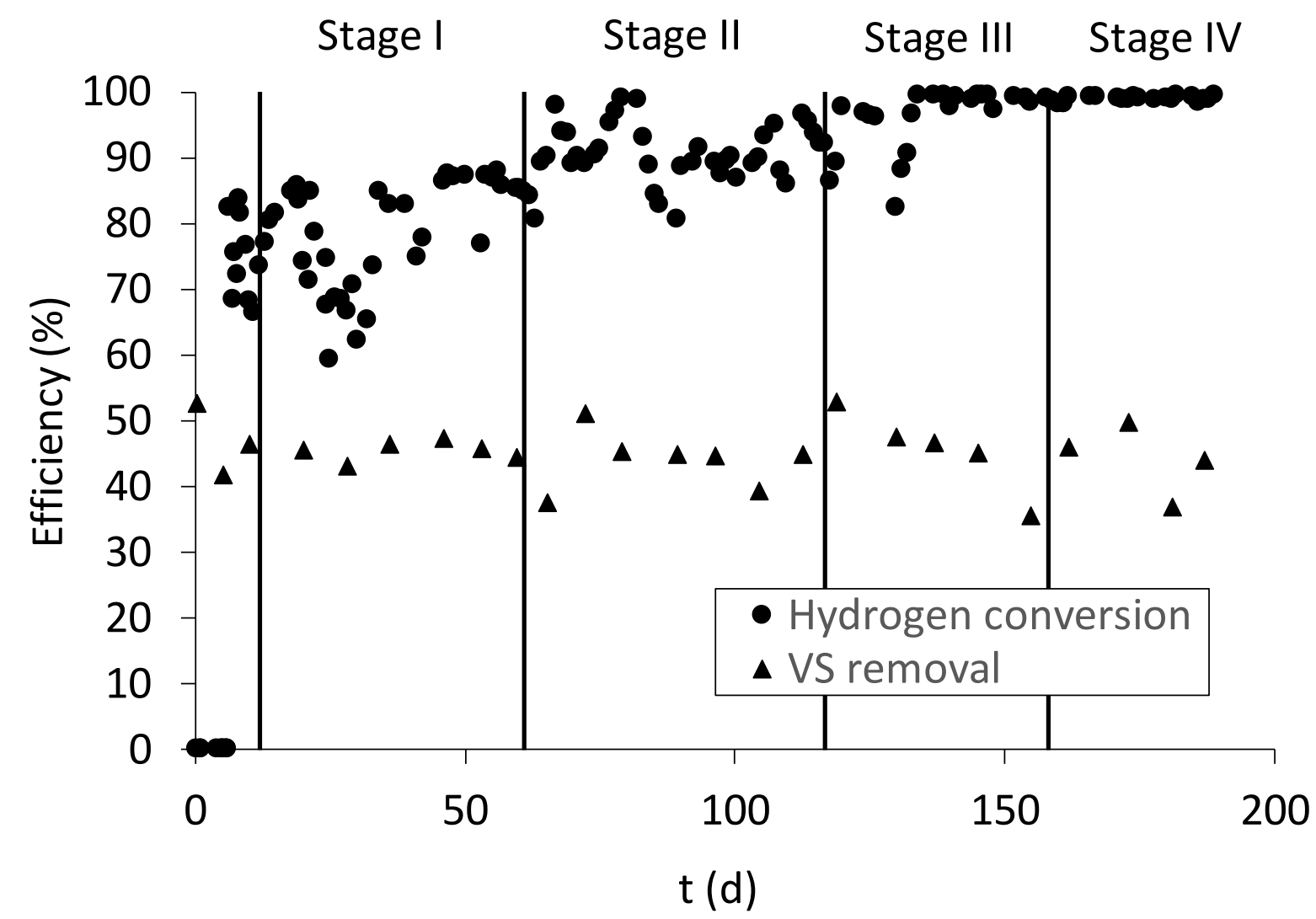

Figure 4. Efficiencies of $\mathrm{H}_{2}$ conversion and organic matter removal.

Total gas productivity in the digester (Figure 5) was mainly affected by two factors. Firstly, OLR, which was variable during the study according to the VS concentration in raw sludge as in full-scale sludge digesters and, secondly, the efficiency of the conversion of $\mathrm{H}_{2}$ and $\mathrm{CO}_{2}$ to $\mathrm{CH}_{4}$ (Figure 4). In this regard, greater gas productivity can be expected when OLR increases (OLR was higher in stages III and IV than in stages I and II) and, additionally, a more significant $\eta_{\mathrm{H} 2}$ causes a reduction in the total gas production rate because $5 \mathrm{~mol}$ of gases ( $4 \mathrm{~mol}$ of $\mathrm{H}_{2}$ and 1 of $\mathrm{CO}_{2}$ ) produce only $1 \mathrm{~mol}$ of $\mathrm{CH}_{4}$ (Eq.1). In contrast, the flowrate of $\mathrm{CH}_{4}$ is increased both by increasing OLR and $\eta_{\mathrm{H} 2}$, and this was the trend observed during the study. From an average $\mathrm{CH}_{4}$ flowrate of $0.30 \pm 0.07 \mathrm{NLCH}_{4} \mathrm{~L}_{\mathrm{r}} \mathrm{d}^{-1}$ in stage I, a similar flowrate $\left(0.29 \pm 0.05 \mathrm{NL}_{\mathrm{CH} 4} \mathrm{~L}_{\mathrm{r}} \mathrm{d}^{-1}\right)$ was detected in stage II despite the greater $\eta_{\mathrm{H} 2}$ presumably because of a slight decrease in OLR. Later, $\mathrm{CH}_{4}$ flowrate increased to $0.43 \pm 0.10 \mathrm{NL}_{\mathrm{CH}}$ $\mathrm{L}_{\mathrm{r}} \mathrm{d}^{-1}$ in stage IV and to $0.50 \pm 0.06 \mathrm{NL}_{\mathrm{CH} 4} \mathrm{~L}_{\mathrm{r}} \mathrm{d}^{-1}$ because of both the higher OLR and $\eta_{\mathrm{H} 2}$ observed. 


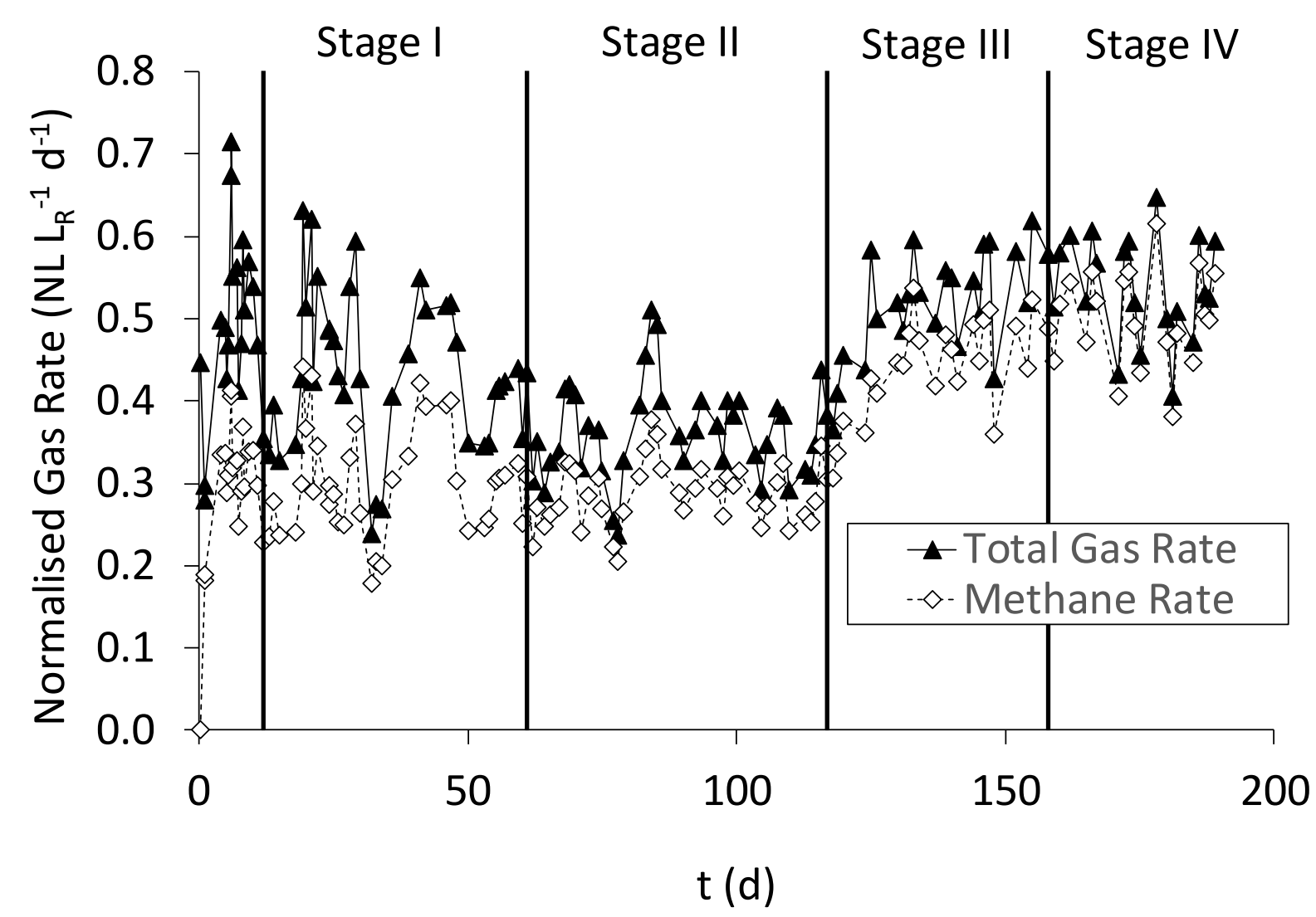

Figure 5. Normalised gas productivity during the experiment.

The average gas productivity during stage IV was $0.54 \pm 0.06 \mathrm{NL} \mathrm{L}_{\mathrm{r}}^{-1} \mathrm{~d}^{-1}$, lower than that observed during the reference conventional $\mathrm{AD}$ at atmospheric pressure $\left(0.66 \pm 0.16 \mathrm{NL} \mathrm{Lr}^{-1} \mathrm{~d}^{-1}\right)$; however, $\mathrm{CH}_{4}$ productivity $\left(0.50 \pm 0.05 \mathrm{NL}_{\mathrm{CH} 4} \mathrm{~L}_{\mathrm{r}}^{-1} \mathrm{~d}^{-1}\right)$ was $16 \%$ higher than that of conventional AD $(0.43 \pm 0.08$ NL $\left.\mathrm{L}_{\mathrm{r}}^{-1} \mathrm{~d}^{-1}\right)$. Under the hypothesis that the conditions applied in stage IV did not alter significantly VS removal (discussed in section 3.4), the complete conversion of $\mathrm{H}_{2}$ to $\mathrm{CH}_{4}$ according to the stoichiometry of hydrogenotrophic methanogenesis could result in maximum $\mathrm{CH}_{4}$ productivity of 0.59 NL $L_{r}^{-1} d^{-1}\left(0.43 \mathrm{NL} \mathrm{Lr}^{-1} \mathrm{~d}^{-1}\right.$ from VS removal plus $0.16 \mathrm{NL} \mathrm{Lr}^{-1} \mathrm{~d}^{-1}$ from $\mathrm{H}_{2}$ and $\mathrm{CO}_{2}$ conversion) for stage IV. Despite the large $\mathrm{H}_{2}$ conversion efficiency during stage IV $(99.0 \pm 0.4 \%)$, as shown in Figure 3 , the $\mathrm{CH}_{4}$ productivity was approximately $15 \%$ lower than the maximum. A slightly lower OLR in stage IV in comparison to the reference period (1.20 vs. $1.3 \mathrm{gVS} \mathrm{Lr}^{-1} \mathrm{~d}^{-1}$ ) and the utilisation of $\mathrm{H}_{2}$ for microbial growth, estimated at $16-19 \%$ of consumed $\mathrm{H}_{2}$ [23], are the main reasons behind this discrepancy.

Dissolved $\mathrm{CH}_{4}$ calculated according to Henry's Law $\left(3.8 \cdot 10^{-3} \mathrm{NL} \mathrm{Lr}_{\mathrm{r}}^{-1} \mathrm{~d}^{-1}\right.$ for $300 \mathrm{kPa}$ and $\left.95 \% \mathrm{CH}_{4}\right)$ can be neglected for mass balances purposes because it is infinitesimally small and represents less than $1 \%$ of total $\mathrm{CH}_{4}$ production. However, this value is 4.3 times the value calculated for conventional AD 
(atmospheric pressure and $66 \% \mathrm{CH}_{4}$ ), and supersaturation of dissolved $\mathrm{CH}_{4}$ has been previously reported in effluents from $\mathrm{AD}$ [36]. To prevent diffuse emissions of $\mathrm{CH}_{4}$ from digested sludge, dissolved $\mathrm{CH}_{4}$ should be quantified in future research for appropriate management and recovery of dissolved $\mathrm{CH}_{4}$.

\subsection{Estimation of the specific mass transfer coefficient $\left(k_{L} a\right)$}

The specific mass transfer coefficient of $\mathrm{H}_{2}$ was estimated (Eq.3) considering a simplified plug flow regime in the recirculation stream (laminar flow), pure $\mathrm{H}_{2}$ dispersed bubbles ascending in the digester $\left(\mathrm{P}_{\mathrm{H} 2}\right.$ is the operating pressure for every stage $)$ and a negligible concentration of dissolved $\mathrm{H}_{2}\left(\mathrm{C}_{\mathrm{H} 2 \mathrm{~L}}=\right.$ 0 ). Estimated values are quite low in the range of 0.4-0.5 $\mathrm{h}^{-1}$ (Figure 6). Reported $\mathrm{k}_{\mathrm{L}}$ a values for $\mathrm{H}_{2}$ in lab-scale digesters supplied with exogenous $\mathrm{H}_{2}$ are between $6.6 \mathrm{~h}^{-1}$ and $16 \mathrm{~h}^{-1}$ employing diffusers and mechanical stirring [19] and $25 \mathrm{~h}^{-1}$ in digesters mixed by gas recirculation through membranes and bubbling [23]. The low $\mathrm{k}_{\mathrm{L}}$ a values observed in this study suggest that the contribution of the static mixer to increase mass transfer was poor. Nonetheless, kLa value in this study could be slightly underestimated chiefly because of two reasons: the continuous desorption of $\mathrm{CH}_{4}$ generation might have reduced the $\mathrm{P}_{\mathrm{H} 2}$ in ascending bubbles and because of neglecting the concentration of dissolved $\mathrm{H}_{2}\left(\mathrm{C}_{\mathrm{H} 2 \mathrm{~L}}\right)$. However, it should be noted that for low to moderate OLR rates and large HRT, such as in this study, a $\mathrm{H}_{2}$ flowrate of $0.64 \mathrm{NL} \mathrm{L}_{\mathrm{r}}^{-1} \mathrm{~d}^{-1}$ would require $\mathrm{k}_{\mathrm{L}}$ a values around $\sim 5 \mathrm{~h}^{-1}$ at atmospheric pressure to achieve a concentration of $\mathrm{CH}_{4}$ of $95 \%$ according to simulations performed elsewhere [37]. The increase in the driving-force provoked by a greater operating pressure would result in very low $\mathrm{k}_{\mathrm{La}}$ values, sufficient to achieve high conversion efficiencies by employing low-efficiency mixing devices at laminar flow regimes in the sludge recirculation stream, such as the static mixer used in this research or with Venturi-type mixers as in [26]. 


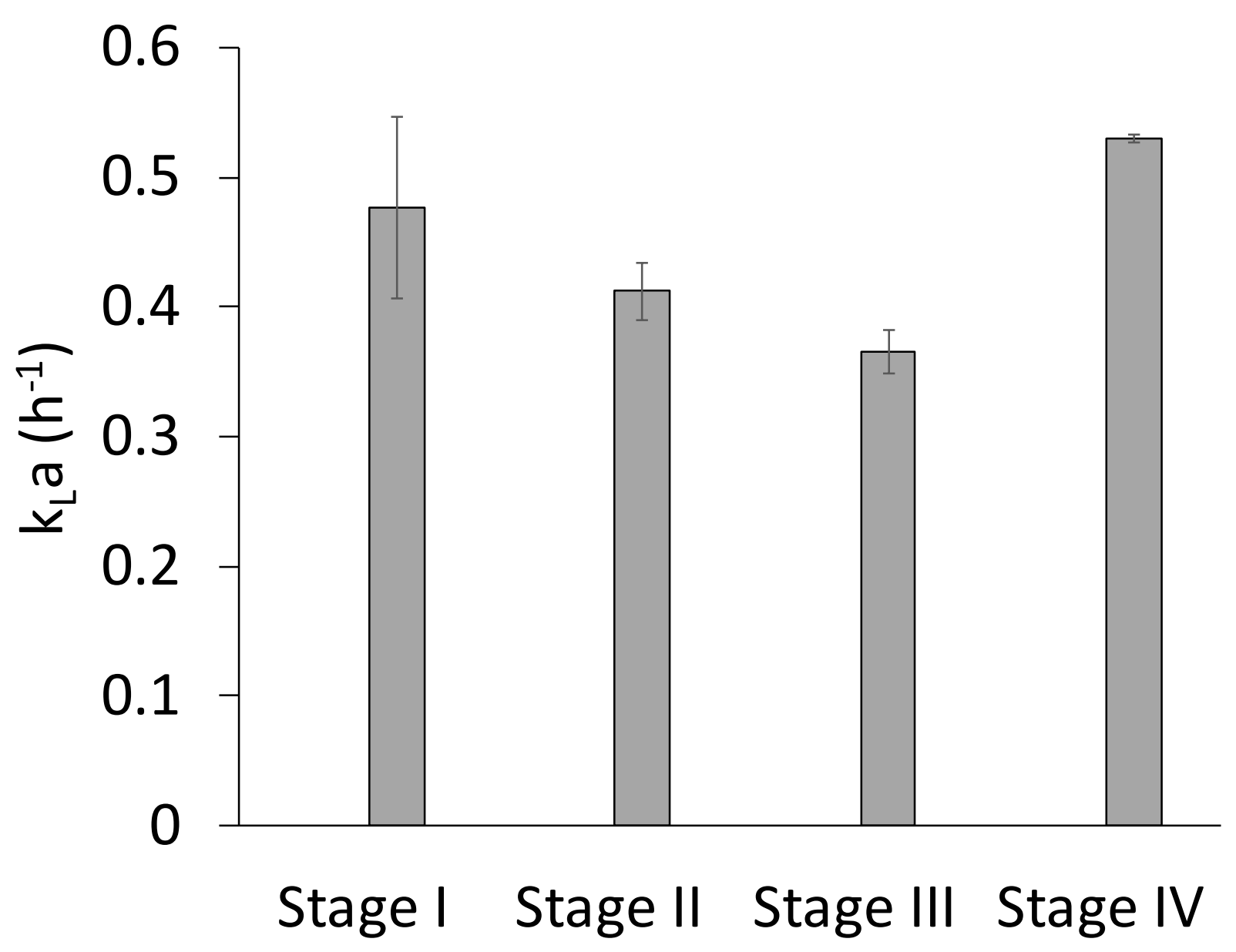

Figure 6. Estimated mass transfer coefficients in various stages

\subsection{Evolution of pH}

$\mathrm{pH}$ in the digester dropped to an average value of $6.6 \pm 0.2$ (down to 6.4) during stage I of the experiment (Figure 7.a) but later recovered when $\mathrm{H}_{2}$ conversion increased, to $6.8 \pm 0.1$ in stage II and III and, particularly, in stage IV to $7.0 \pm 0.1$. In this regard, the hypothesis that $\mathrm{H}_{2}$ supply controlled the $\mathrm{pH}$ in the pressurised system was confirmed and prevented acidification caused by $\mathrm{CO}_{2}$ equilibrium displacement in the liquid phase observed at high operating pressure values [29]. The drop in $\mathrm{pH}$ during the first stages of the experiment, particularly in stage I, was presumably as a result of the $\mathrm{CO}_{2} / \mathrm{HCO}_{3}$ equilibrium displacement at low $\mathrm{H}_{2}$ utilisation rates (60-85\%, Figure 4). Conversely, concentration of $\mathrm{CH}_{4}$ greater than $90 \%$ was observed at $\mathrm{pH} 7.0$ in stage IV at $300 \mathrm{kPa}$, while reported $\mathrm{pH}$ in studies of anaerobic digesters was higher than $8[16,18,23-25]$ (Figure 7.b). Higher solubilisation of $\mathrm{H}_{2}$ contributed to $\mathrm{pH}$ stabilisation around 7 at stages III and IV. 

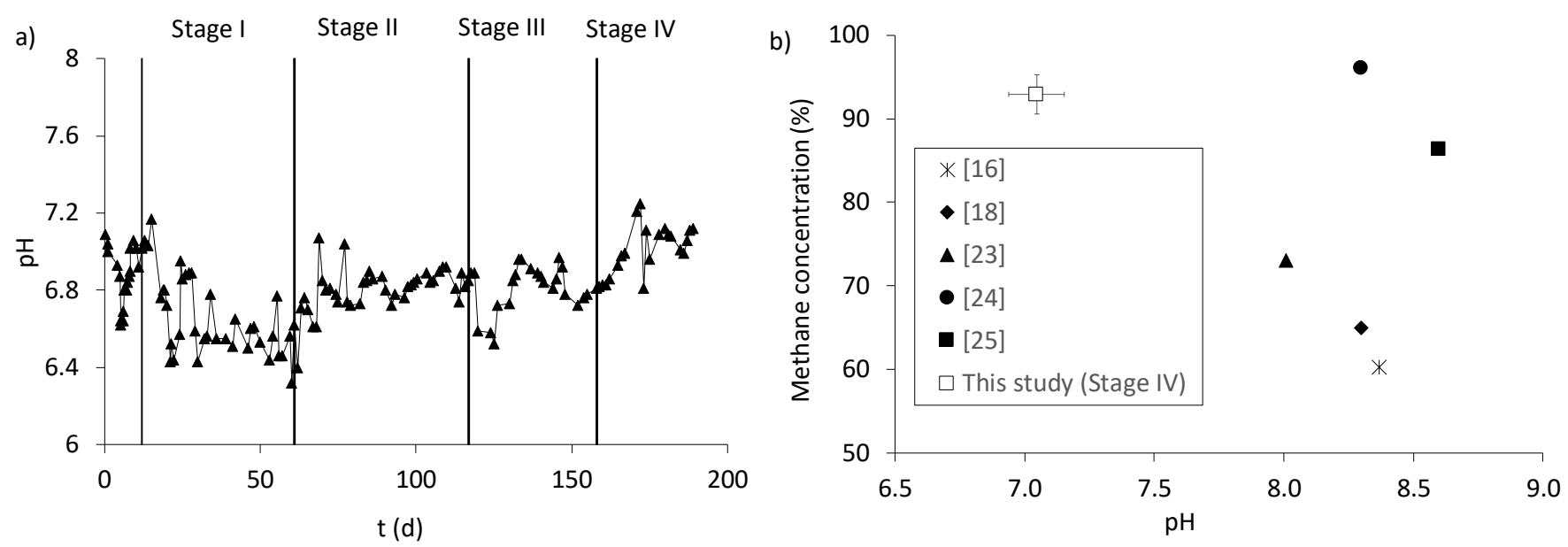

Figure 7. Evolution of $\mathrm{pH}$ during the study (a). $\mathrm{pH}$ and $\mathrm{CH}_{4}$ concentration in anaerobic digesters with exogenous $\mathrm{H}_{2}$ supply (b).

It should be pointed out that, even when a neutral $\mathrm{pH}$ was observed in the latter stages, at high $\mathrm{H}_{2}$ conversion rates and $300 \mathrm{kPa}$, the system reached a state of very low alkalinity because of $\mathrm{CO}_{2}$ methanation. In this regard, previous studies reporting the evolution of $\mathrm{pH}$ under the supply of exogenous $\mathrm{H}_{2}$ to anaerobic digesters were performed at OLR between 1.6 and $1.9 \mathrm{gVS} \mathrm{L}^{-1} \mathrm{~d}^{-1}[18,23-$ 25] and $4 \mathrm{gVS} \mathrm{L}^{-1} \mathrm{~d}^{-1}$ [16]. Sudden increases in the OLR, intrinsic to the sludge generation process in the WWTP, could result in a breakdown of the process because of no or inferior buffer capacity.

\subsection{Organic matter removal and VFA accumulation}

The efficiency of VS removal (Figure 4) was, on average, $45.2 \pm 4.3 \%$ (26 observations) throughout the experiment, within the typical values for AD of sludge at atmospheric pressure [38] for low OLR. The average VS removal of the reference data for conventional AD was $48.2 \pm 7.5 \%$ (14 observations). For a confidence level of $95 \%(\alpha=0.05)$, the hypothesis of no difference between both averages adopting an unequal variances $t$-test gave a $p$-value of 0.08 , larger than $\alpha$; then, the hypothesis cannot be rejected, and VS removal efficiency during the experiment was similar to that observed during the conventional AD.

Combining the observations in section 3.1 and the performance of the organic matter removal, the estimated productivity of $\mathrm{CH}_{4}\left({\mathrm{~mL} \mathrm{gVS}_{\text {fed }}}^{-1}\right)$ from organic matter during stage IV was $\sim 93 \%$ of expected (44.8\% VS removal vs. $48.2 \%$ in the reference AD) and that from methanogenesis of exogenous $\mathrm{H}_{2}$ and $\mathrm{CO}_{2}$ was stoichiometrically approximately $82 \%$ of the maximum ( 0.13 vs. 0.16 $\left.\mathrm{NL} \mathrm{L}_{\mathrm{r}}^{-1} \mathrm{~d}^{-1}\right)$. Therefore, $\mathrm{CH}_{4}$ productivity in stage IV $\left(0.50 \pm 0.05 \mathrm{NL}_{\mathrm{CH} 4} \mathrm{Lr}_{\mathrm{r}}^{-1} \mathrm{~d}^{-1}\right)$ was the sum of $\sim 0.37$ 
$\mathrm{NL}_{\mathrm{CH} 4} \mathrm{~L}_{\mathrm{r}}^{-1} \mathrm{~d}^{-1}$ from VS removal (74\%) and $\sim 0.13 \mathrm{NL}_{\mathrm{CH} 4} \mathrm{~L}_{\mathrm{r}}^{-1} \mathrm{~d}^{-1}$ from the methanation of $\mathrm{H}_{2}$ and $\mathrm{CO}_{2}$. In this sense, the contribution of the different metabolic pathways of $\mathrm{CH}_{4}$ production (hydrogenotrophic and acetoclastic) is of interest because methanogenic microbial communities have shown adaptation to exogenous $\mathrm{H}_{2}$ as well as a significant production of acetate through homoacetogenesis [27]. While the methods here employed do not allow distinguishing the rate at which hydrogenotrophic and acetoclastic methanogenesis took place, an equilibrium was observed because of the lack of VFA accumulation.

Acetate concentration was below $40 \mathrm{mg} \mathrm{L}^{-1}$ in 18 out of 20 observations and two peaks of 650 and 240 $\mathrm{mg} \mathrm{L}^{-1}$ were found on days 19 and 125 respectively (Figure 8.a). These peaks were attributed to transient states and, overall, acetate accumulation was not observed thus indicating a lack of undesired conversion of $\mathrm{H}_{2}$ into acetate. Propionate and butyrate concentrations were below 18 and $38 \mathrm{mg} \mathrm{L}^{-1}$, respectively, during the whole experiment (20 observations). Variations in the OLR could be the reason behind these peaks; an increase in VS concentration in raw sludge occurred on days 19 and 125. To a lesser extent, a similar behaviour was observed in day 42 (Figure 8.a). In this regard, sludge digestion is sharply limited by the hydrolysis step and overloads are less common than in anaerobic bioreactors processing readily biodegradable substrates.
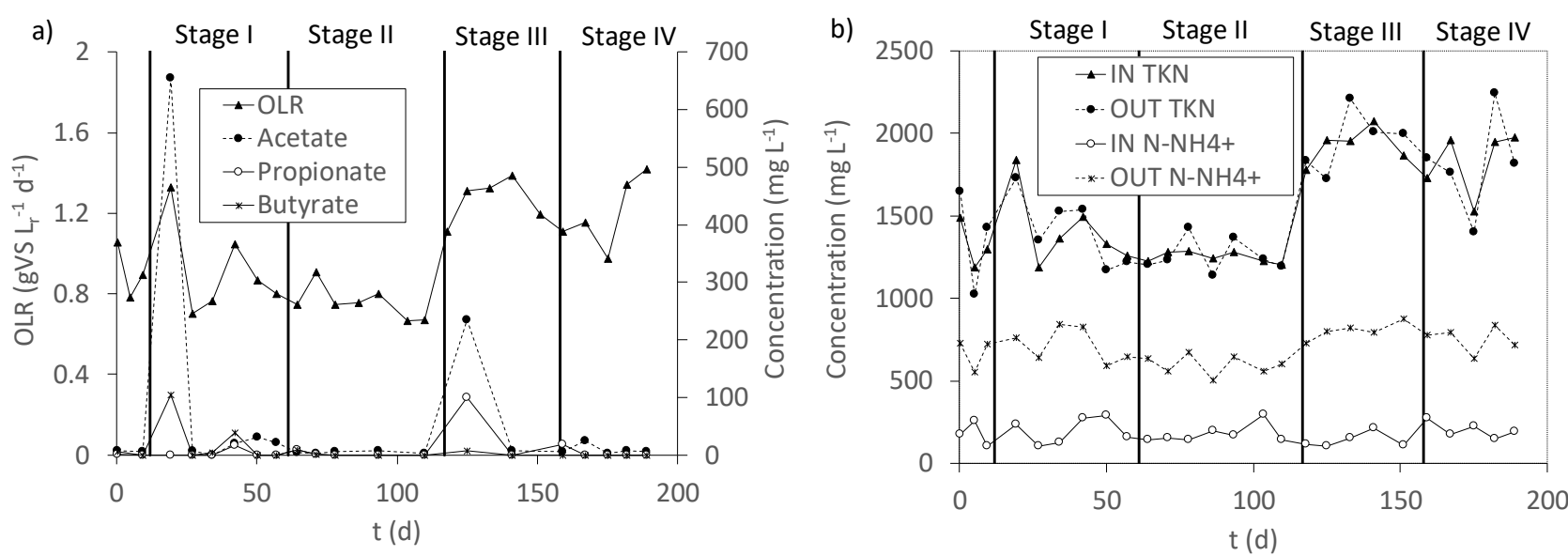

Figure 8. OLR and concentrations of volatile fatty acids (acetate, propionate and butyrate) during the study (a). Evolution of TKN and $\mathrm{N}-\mathrm{NH}_{4}{ }^{+}$(b).

With respect to the evolution of $\mathrm{N}$ species during the experiment, $\mathrm{TKN}$ and $\mathrm{N}-\mathrm{NH}_{4}{ }^{+}$concentrations remained within the typical values in the conventional AD of sludge (Figure 8.b); inlet and outlet TKN were practically equal and N-NH${ }_{4}^{+}$concentrations increased during $\mathrm{AD}$ (up to $875 \mathrm{mg} \mathrm{L}^{-1}$ ). Inhibition by ammonia is favoured at high $\mathrm{pH}$, where equilibrium is displaced to form $\mathrm{NH}_{3}$; the operation at a 
neutral $\mathrm{pH}$ assists to prevent inhibition by $\mathrm{NH}_{3}$.

Essentially, no evidence was found to support that methanogenesis was inhibited by the pressure increase or the supply of exogenous $\mathrm{H}_{2}$. In this regard, methanogens had also shown tolerance to moderate operating pressures (up to $900 \mathrm{kPa}$ ) before [29], and the high $\mathrm{P}_{\mathrm{H} 2}$, which thermodynamically could inhibit syntrophic fermentations [37], did not show an accumulation of VFA during the study. The latter effect might be favoured because sludge digestion is limited by the hydrolysis step. The low VFA concentration observed is in agreement with the lack of inhibition of syntrophic fermentation indicating that the methanogenesis/homoacetogenesis rates were high enough to cope with $\mathrm{H}_{2}$ production from organic matter and to sustain both organic matter removal and $\mathrm{CO}_{2}$ methanation. Therefore, most of the $\mathrm{H}_{2}$ content in the gas is presumably the result of the exogenous supply.

\subsection{Perspectives and future work}

It was feasible to achieve a high concentration of $\mathrm{CH}_{4}(>90 \%)$ directly from the anaerobic digester and a neutral $\mathrm{pH}$ with a continuous supply of exogenous $\mathrm{H}_{2}$ by increasing the operating pressure. However, several challenges arise for the scale-up of the process. The absence of buffer capacity could result in process inhibition and accumulation of VFA at higher OLR than this study, and stationary operation of the system must be assessed. Further, a higher OLR might require higher operating pressure to transfer enough $\mathrm{H}_{2}$ for a greater $\mathrm{CO}_{2}$ flowrate or alternatively, an increase in the specific mass transfer coefficient. Apart from that, the extension of this application (high pressure and $\mathrm{H}_{2}$ supply) to other kinds of anaerobic bioreactors such as UASB or similar treating soluble organic matter, limited by methanogenesis rather than hydrolysis, could be infeasible because of the greater intermediate concentration of dissolved $\mathrm{H}_{2}$ associated to syntrophic fermentations.

From an energetic point of view, the pressure is autogenerated by gas generation from VS, and a moderate operating pressure was required in this study to achieve high $\mathrm{H}_{2}$ conversion (300 $\mathrm{kPa}$, implying a lower energy requirement; only additional power for pumping the sludge and the $\mathrm{H}_{2}$ stream to a higher pressure can be expected), in contrast to forcing the conversion of $\mathrm{H}_{2}$ using high biogas or liquid recirculation rates in the reactor or sophisticated $\mathrm{H}_{2}$ transfer systems with the consequent increase in the net energy consumption of the process. Therefore, lower operating costs can be expected by raising the operating pressure (driving-force) than those of increasing the specific mass transfer coefficient $\left(\mathrm{k}_{\mathrm{L}} \mathrm{a}\right)$ by mixing. On the contrary, fixed costs are expected to increase notably in because of the wall thickness necessary to withstand a pressure higher than the atmospheric. In this regard, the better pressure distribution expected in egg-shaped digesters or a reduced diameter to length 
ratio $(\mathrm{D} / \mathrm{L})$ could also help to contain fixed costs.

\section{Conclusions}

Biomethane with a concentration above $90 \%$ was produced directly from an anaerobic digester of sewage sludge with exogenous hydrogen supply by raising the operating pressure to $300 \mathrm{kPa}$. Hydrogen mass transfer to the liquid phase was favoured by increasing the driving force, and hydrogen conversion reached $99 \%$ under such conditions. The contribution of the removal of organic matter to methane production was approximately $74 \%$ and that from the methanation of hydrogen and carbon dioxide the remaining $26 \%$. The expected decrease in $\mathrm{pH}$, caused by the higher carbon dioxide concentration in the liquid, was counteracted by the utilisation of hydrogen in methanogenesis, hence converting carbon dioxide into methane, and $\mathrm{pH}$ could be maintained around neutral values (7) when a high hydrogen conversion was achieved. Besides, the efficiency of organic matter removal during the experiment was not significantly different from that of conventional anaerobic digestion at atmospheric pressure, and no persistent accumulation of volatile fatty acids or inhibition of methanogenesis was observed.

\section{Acknowledgements}

This work was supported by the Regional Government of Castilla y León, the EU-FEDER (CLU 201709 and UIC 071) and the University of Valladolid (Postdoctoral Fellowships).

The authors would like to express their hearty thanks to Dr. Sheena and the Institute for Water and Wastewater Technology, Dr. Chetty and the Chemical Engineering Department, DUT.

\section{References}

[1] Nasir IM, Mohd Ghazi TI, Omar R. Anaerobic digestion technology in livestock manure treatment for biogas production: A review. Eng Life Sci 2012;12:258-69. https://doi.org/10.1002/elsc.201100150.

[2] Mata-Alvarez J, Macé S, Llabrés P. Anaerobic digestion of organic solid wastes. An overview of research achievements and perspectives. Bioresour Technol 2000;74:3-16. https://doi.org/https://doi.org/10.1016/S0960-8524(00)00023-7.

[3] Ragauskas AJ, Williams CK, Davison BH, Britovsek G, Cairney J, Eckert CA, et al. The Path Forward for Biofuels and Biomaterials. Science (80- ) 2006;311:484 LP - 489. https://doi.org/10.1126/science.1114736.

[4] Bahrs E, Angenendt E. Status quo and perspectives of biogas production for energy and material utilization. GCB Bioenergy 2019;11:9-20. https://doi.org/10.1111/gcbb.12548. 
[5] Muñoz R, Meier L, Diaz I, Jeison D. A review on the state-of-the-art of physical/chemical and biological technologies for biogas upgrading. Rev Environ Sci Bio/Technology 2015;14:72759. https://doi.org/10.1007/s11157-015-9379-1.

[6] Scarlat N, Dallemand J-F, Fahl F. Biogas: Developments and perspectives in Europe. Renew Energy 2018;129:457-72. https://doi.org/https://doi.org/10.1016/j.renene.2018.03.006.

[7] Alcántara C, García-Encina PA, Muñoz R. Evaluation of mass and energy balances in the integrated microalgae growth-anaerobic digestion process. Chem Eng J 2013;221:238-46. https://doi.org/10.1016/J.CEJ.2013.01.100.

[8] O'Shea R, Wall DM, McDonagh S, Murphy JD. The potential of power to gas to provide green gas utilising existing $\mathrm{CO} 2$ sources from industries, distilleries and wastewater treatment facilities. Renew Energy 2017;114:1090-100.

https://doi.org/https://doi.org/10.1016/j.renene.2017.07.097.

[9] Götz M, Lefebvre J, Mörs F, McDaniel Koch A, Graf F, Bajohr S, et al. Renewable Power-toGas: A technological and economic review. Renew Energy 2016;85:1371-90. https://doi.org/10.1016/j.renene.2015.07.066.

[10] Thema M, Weidlich T, Hörl M, Bellack A, Mörs F, Hackl F, et al. Biological CO 2 Methanation: An Approach 2019:1-32.

[11] Burkhardt M, Jordan I, Heinrich S, Behrens J, Ziesche A, Busch G. Long term and demandoriented biocatalytic synthesis of highly concentrated methane in a trickle bed reactor. Appl Energy 2019;240:818-26. https://doi.org/10.1016/J.APENERGY.2019.02.076.

[12] Dupnock TL, Deshusses MA. Detailed investigations of dissolved hydrogen and hydrogen mass transfer in a biotrickling filter for upgrading biogas. Bioresour Technol 2019;290:121780. https://doi.org/10.1016/j.biortech.2019.121780.

[13] Porté H, Kougias PG, Alfaro N, Treu L, Campanaro S, Angelidaki I. Process performance and microbial community structure in thermophilic trickling biofilter reactors for biogas upgrading. Sci Total Environ 2019;655:529-38. https://doi.org/10.1016/j.scitotenv.2018.11.289.

[14] Savvas S, Donnelly J, Patterson T, Chong ZS, Esteves SR. Biological methanation of CO2 in a novel biofilm plug-flow reactor: A high rate and low parasitic energy process. Appl Energy 2017;202:238-47. https://doi.org/10.1016/j.apenergy.2017.05.134.

[15] Patterson T, Savvas S, Chong A, Law I, Dinsdale R, Esteves S. Integration of Power to Methane in a waste water treatment plant - A feasibility study. Bioresour Technol 2017;245:1049-57. https://doi.org/10.1016/j.biortech.2017.09.048.

[16] Voelklein MA, Rusmanis D, Murphy JD. Biological methanation: Strategies for in-situ and 
ex-situ upgrading in anaerobic digestion. Appl Energy 2019;235:1061-71. https://doi.org/10.1016/J.APENERGY.2018.11.006.

[17] Lecker B, Illi L, Lemmer A, Oechsner H. Biological hydrogen methanation - A review. Bioresour Technol 2017;245:1220-8. https://doi.org/10.1016/j.biortech.2017.08.176.

[18] Luo G, Johansson S, Boe K, Xie L, Zhou Q, Angelidaki I. Simultaneous hydrogen utilization and in situ biogas upgrading in an anaerobic reactor. Biotechnol Bioeng 2012;109:1088-94. https://doi.org/10.1002/bit.24360.

[19] Luo G, Angelidaki I. Co-digestion of manure and whey for in situ biogas upgrading by the addition of $\mathrm{H} 2$ : process performance and microbial insights. Appl Microbiol Biotechnol 2013;97:1373-81. https://doi.org/10.1007/s00253-012-4547-5.

[20] Bassani I, Kougias PG, Treu L, Angelidaki I. Biogas Upgrading via Hydrogenotrophic Methanogenesis in Two-Stage Continuous Stirred Tank Reactors at Mesophilic and Thermophilic Conditions. Environ Sci Technol 2015:151001074540007. https://doi.org/10.1021/acs.est.5b03451.

[21] Wahid R, Mulat DG, Gaby JC, Horn SJ. Effects of H2:CO2 ratio and H2 supply fluctuation on methane content and microbial community composition during in-situ biological biogas upgrading. Biotechnol Biofuels 2019;12:1-15. https://doi.org/10.1186/s13068-019-1443-6.

[22] Mulat DG, Mosbæk F, Ward AJ, Polag D, Greule M, Keppler F, et al. Exogenous addition of H2for an in situ biogas upgrading through biological reduction of carbon dioxide into methane. Waste Manag 2017;68:146-56. https://doi.org/10.1016/j.wasman.2017.05.054.

[23] Alfaro N, Fdz-Polanco M, Fdz-Polanco F, Díaz I. H2 addition through a submerged membrane for in-situ biogas upgrading in the a naerobic digestion of sewage sludge. Bioresour Technol 2019;280:1-8. https://doi.org/10.1016/J.BIORTECH.2019.01.135.

[24] Luo G, Angelidaki I. Hollow fiber membrane based H2 diffusion for efficient in situ biogas upgrading in an anaerobic reactor. Appl Microbiol Biotechnol 2013;97:3739-44. https://doi.org/10.1007/s00253-013-4811-3.

[25] Corbellini V, Kougias PG, Treu L, Bassani I, Malpei F, Angelidaki I. Hybrid biogas upgrading in a two-stage thermophilic reactor. Energy Convers Manag 2018;168:1-10. https://doi.org/10.1016/J.ENCONMAN.2018.04.074.

[26] Jensen MB, Kofoed MVW, Fischer K, Voigt NV, Agneessens LM, Batstone DJ, et al. Venturi-type injection system as a potential $\mathrm{H} 2$ mass transfer technology for full-scale in situ biomethanation. Appl Energy 2018;222:840-6. https://doi.org/10.1016/J.APENERGY.2018.04.034.

[27] Agneessens LM, Ottosen LDM, Voigt NV, Nielsen JL, de Jonge N, Fischer CH, et al. In-situ 
biogas upgrading with pulse $\mathrm{H} 2$ additions: The relevance of methanogen adaption and inorganic carbon level. Bioresour Technol 2017;233:256-63.

https://doi.org/10.1016/J.BIORTECH.2017.02.016.

[28] Lindeboom REF, Fermoso FG, Weijma J, Zagt K, van Lier JB. Autogenerative high pressure digestion: anaerobic digestion and biogas upgrading in a single step reactor system. Water Sci Technol 2011;64:647. https://doi.org/10.2166/wst.2011.664.

[29] Lindeboom REF, Ferrer I, Weijma J, van Lier JB. Silicate minerals for CO2 scavenging from biogas in Autogenerative High Pressure Digestion. Water Res 2013;47:3742-51. https://doi.org/10.1016/j.watres.2013.04.028.

[30] Martin MR, Fornero JJ, Stark R, Mets L, Angenent LT. A single-culture bioprocess of Methanothermobacter thermautotrophicus to upgrade digester biogas by $\mathrm{CO} 2$-to- $\mathrm{CH} 4$ conversion with H2. Archaea 2013;2013:157529. https://doi.org/10.1155/2013/157529.

[31] Ullrich T, Lindner J, Bär K, Mörs F, Graf F, Lemmer A. Influence of operating pressure on the biological hydrogen methanation in trickle-bed reactors. Bioresour Technol 2018;247:713. https://doi.org/10.1016/J.BIORTECH.2017.09.069.

[32] Díaz I, Lopes AC, Pérez SI, Fdz-Polanco M. Performance evaluation of oxygen, air and nitrate for the microaerobic removal of hydrogen sulphide in biogas from sludge digestion. Bioresour Technol 2010;101:7724-30. https://doi.org/10.1016/j.biortech.2010.04.062.

[33] Alcántara C, Fernández C, García-Encina P, Muñoz R, Alcántara C, C F, et al. Mixotrophic metabolism of Chlorella sorokiniana and algal-bacteria consortia under extended dark-light periods and nutrient starvation. Appl Microbiol Biotechnol 2014;99:2393-404. https://doi.org/10.1007/s00253-014-6125-5.

[34] APHA. Standard Methods for the Examination of Water and Wastewater. 2012.

[35] Sanders R. Henry's Law Constants. In: Linstrom PJ, Mallard WG, editors. NIST Chem. WebBook, NIST Stand. Ref. Database Number 69, Gaithersburg MD 20899: National Institute of Standards and Technology; 2018. https://doi.org/10.18434/T4D303.

[36] Souza CL, Chernicharo CAL, Aquino SF. Quantification of dissolved methane in UASB reactors treating domestic wastewater under different operating conditions. Water Sci Technol 2011;64:2259-64. https://doi.org/10.2166/wst.2011.695.

[37] Bensmann A, Hanke-Rauschenbach R, Heyer R, Kohrs F, Benndorf D, Reichl U, et al. Biological methanation of hydrogen within biogas plants: A model-based feasibility study. Appl Energy 2014;134:413-25. https://doi.org/10.1016/j.apenergy.2014.08.047.

[38] Appels L, Baeyens J, Degrève J, Dewil R. Principles and potential of the anaerobic digestion of waste-activated sludge. Prog Energy Combust Sci 2008;34:755-81. 
https://doi.org/10.1016/J.PECS.2008.06.002.

[39] Speece RE. Anaerobic biotechnology and odor/corrosion control for municipalities and industries. Archaea Press; 2008.

[40] Soto M, Méndez R, Lema JM, Compostela S De. Methanogenic and Non-Methanogenic Activity Tests . Theoretical Basis and Experimental Set Up. Water Res 1993;27:1361-76. https://doi.org/10.1016/0043-1354(93)90224-6. 